MANAGEMENT AND MARKETING

\title{
GEORGIAN MENTALITY IN THE FIELD OF BUSINESS CULTURE
}

\author{
Iasha Murvanidze, Assistant professor of Black Sea International University, Tbilisi, Georgia \\ Giorgi Meishvili, PhD in Business Administration, Tbilisi, Georgia
}

DOI: https://doi.org/10.31435/rsglobal_conf/25062021/7605

\begin{abstract}
Despite of our countries active participation in the process of globalization, there are many problems. One of the essential aspects for solving these problems is a correct and complete logic in terms of making the right decisions necessary for obtaining proper information by the governmental agencies, managers and businessmen, company owners, large and private entrepreneurs.

Not all tasks that life puts before us can be solved by the means of logic for it requires the use of different types of thinking - creative or lateral. The ability to think flexibly, reviewing the problem from different angles and solving it before others do it, are essential skills without which personal and professional success is impossible.
\end{abstract}

Keywords: business culture, comparative management, business culture system, lateral thinking, mental activity.

Introduction. The research objective is the processes of revealing, creating, introducing and applying the peculiarities of the business cultures that are necessary for the formation of the Georgian business culture system, in general. Edward de Bono, a world-renowned popularizer of lateral thinking methodology believes that the use of mental techniques is effective in business, creativity and personal life. According to de Bono's concept, transition to a new economic formation raises the issue of competitiveness of local products in the world market. Today, the entrepreneur, a businessman, will achieve real success only if he/she launches products of a level close to the world standards, manages to offer a similar level of service to the customer, and if he/she wants to export the product - can ensure even a higher quality.

Basic text. The concept associated with the term "lateral thinking" implies a particular approach to mental activity, which pushes our brains to produce new ideas using horizontal creative thinking, as opposed to conventional vertical logical thinking. Creating new ideas, simple and effective (two main purposes of lateral thinking), is a natural activity for the human mind, but in practice vertical thinking can become a hindrance in this regard. Lateral thinking allows you to find the answer to a problem or think of a new situation using a different perspective and a thought process that is not necessarily strictly gradual. Lateral thinking deliberately deviates from "vertical" or logical thinking, as opposed to "horizontal imagination".

Douglas McGregor described two key management models that exist in American management. The traditional model of management - Model $\mathrm{X}$ - is based on the idea that a man is individualistic by nature, focused on meeting his own needs, selfishness and laziness. Model Y focuses on the fact that a person belongs to the community and therefore the goals of the organization are not strange to him, improving the state of an organization also improves the quality of each employee's personal life not only materially, but also psychologically. D. McGregor stressed that Theory $\mathrm{X}$, although quite common, reflects outdated ideas about the human nature. Theory $\mathrm{Y}$ is gaining popularity in the modern world.

Recently, the $\mathrm{Z}$ control model, which is a synthesis of an American and Japanese control models, has been actively developing. It combines individual social values that accompanies the American model of governance, responds to the need for deep-rooted human independence and the modern desire for unification. The function of the management model is that it sets the value-semantic guidelines for managers in dealing with subordinates and determines his or her behavior strategy in terms of management.

Comparative management involves the analysis of the peculiarities of business cultures, the collection of sociological research data and the opinions of specialists, the results of practical interactions between countries, and the development of certain recommendations based on these. In this case, the main practical task is to improve the management system, optimize the management 
processes using the arsenal of comparative management, which leads to increasing the efficiency of the firms as a whole.

The most acceptable way at the moment is the gradual introduction of foreign approaches and their utilization within the Georgian business culture.

Comparing Georgian and American business cultures, a survey intended for Georgian managers has found that they saw more similarities than differences with their American counterparts. The main similarities were the pursuit of success and profit, high levels of activity and energy, independence and patriotism. Among the qualities that Georgian managers lack when compared to Americans were professionalism, business experience, respect for the law, entrepreneurial heritage, belief in the future, punctuality and access to investment sources. In addition, 92\% of respondents expressed concern about the instability of social and personal vulnerability laws and other circumstances. The respondents explain many fundamental differences in the peculiarities of management with the emphasis on the impact external factors to the functioning of Georgian enterprises, as well as the general state of the Georgian economy.

Peculiarities of Georgian business culture influence the formation of a national management style. Peculiarities of decision-making in a particular country are also conditioned by its culture. For example, the European tradition is that entrepreneurs and professional managers pay close attention to the previous experiencea, make more detailed decisions, pay more attention to the quality, in general. As for American managers, they are basically focused on the future. They make decisions faster than others and assign more importance to the act of decision making itself than to its justification. This feature is even more appreciated in Latin American countries, where subordinates expect prompt decision-making from their management.

Georgian managers are characterized by a tendency that neutralizes the possible consequences of irrational decisions. It can be expressed by the formula "wait and see". Georgians avoid solving serious problems by radical measures and prefer palliative solutions. For comparison, the Japanese rely on others when solving problems.

Human behavior in business is influenced by many factors - geographical, social, natural, economic, religious and others, which are then reflected in the formation of certain traditions and habits. These aspects give rise to certain systems of life, upbringing and labor. Moreover, studies show that even during changes in the entrepreneurship, they continue to influence the labor habits and mental characteristics of a significant part of the population.

The main reason for the many negative signs of modern business culture, including the low level of business ethics, is that the slow development of the institutional sphere does not correspond to drastic changes in the value systems. The socialist system, which preached collectivism and the absence of individual values, was replaced by another, free market system based on individual initiative and responsibility. But the radical changes were not accompanied by adequate developments in politics, economics, the social sphere, which led to confusion in definitions and values. It was unclear what was right and what was wrong, ethical or unethical. This applied to both - everyday life and business behaviors.

Nevertheless, the process of integration into the world system, the impact of globalization and membership in the World Trade Organization requires Georgia to develop a certain concept in the field of management. Very often Georgian and foreign scholars agree that some parallels can be drawn between the recognized systems of management in the Western world and their Georgian analogies.

The Georgian style of management is characterized by the following features of the Georgian mentality: attitude towards wealth. The attitude towards wealth, money, profit is traditionally considered to be one of the brightest indicators of the business culture of any society. If in the West wealth was traditionally considered to be the result of a human activity, ability, energy and hard work created by the labor of generations and passed on by inheritance, a person enriched in Georgia was more often associated with dishonesty, being enriched at the expense of others.

After identifying the peculiarities of the Georgian business culture, we come to the following conclusions:

- Georgian business has a number of peculiarities, most of which are reflected in the historical and cultural development of the country;

- Transition to free market relations has led to significant changes in the behavior of the Georgian management style, but at the same time, slow development of the institutional sphere and the value system in Georgia, explains many of negative features of the modern business culture; 
- The manager operating in Georgia should understand these aspects and utilize them for increasing his/her managerial efficiency.

The peculiarities of the economic behavior of any given country are the result of certain events over a long period of time and the conditions of existence of the nation. Business traditions in Georgia were formed under the influence of natural as well as historical-political and social factors, which led to their variability and diversity. For many centuries the principles of entrepreneurship were formed, which are still the basis of human behavior today.

Conclusions. According to experts and entrepreneurs, based on empirical experience and cultural-historical analysis, one of the main formal indicators of the development of Georgian business is its shift to internationalization, as well as the successful incorporation of foreign experiences and comparative management styles.

Positional changes in this direction testify the compatibility of different management models and the readiness of the Georgian labor force to engage in the global economic environment. The optimal options for future development are clearly visible: development of internal markets; long-term complex state planning; Strengthening of state and interstate regulations and most importantly, the following question should be asked: what will be the formula for future success? The development of private businesses, integration of national culture and religion within the general labor environment, as well as the effectiveness of corporate management. Success in governance, good macroeconomic performance, demographics, a successful foreign policy and a strong military can guarantee the economic success. In this regard, the international image of the country, its smart foreign policy and relations with the world superpowers are of immeasurable importance.

\section{REFERENCES}

1 Де Боно Эдвард. Искусство думать. Латеральное мышление как способ решения сложных задач / Де Боно Эдвард. - М.: Альпина Паблишер, 2015. - 172

2 Richard L. Daft New Era of Management $11^{\text {th }}$ ed 2017

3 Potential of Comparative Management and Aspects of its Application in Georgia. Evgeni Baratashvili, Nino Pailodze, Ana Bolkvadze, Giorgi Sulashvili. International Science Index Vol: 9 Paris France Jul 2021, 2015, 17 (7) Part VII. Retrieved from http://waset.org/conference/2015/07/paris/ICBEMM

4 The Features of the Synergistic Approach in Marketing Management to Regional Level. Evgeni Baratashvili, Anzor Abralava, Rusudan Kutateladze, Nino Pailodze, Irma Makharashvili, Larisa Takalandze. 18th International Conference on Economics, Management of Business, Innovation and Technology. International Science Index Vol: London, United Kingdom, May 23-25, 2016. Vol:3, No:18(5), Part XX. 2016. 